\title{
Amphipods from marine cave sediments of the southern Iberian Peninsula: diversity and ecological distribution
}

\author{
Carlos Navarro-Barranco ${ }^{1}$, José Manuel Guerra-García ${ }^{1}$, Luis Sánchez-Tocino ${ }^{2}$, \\ José Carlos García-Gómez ${ }^{1}$ \\ ${ }^{1}$ Laboratorio de Biología Marina, Dpto. Zoología, Facultad de Biología, Universidad de Sevilla. Avda Reina Mercedes 6, \\ 41012 Sevilla, Spain. E-mail: carlosnavarro@us.es \\ ${ }^{2}$ Departamento de Biología Animal, Facultad de Ciencias, Universidad de Granada. Campus Universitario de Fuentenueva, \\ s/n., 18071 Granada, Spain.
}

\begin{abstract}
Summary: The present study explores the amphipod assemblages of six marine caves on the Mediterranean coast of southern Spain. Replicate samples were taken both inside and outside each marine cave in order to characterize the amphipod fauna and the physicochemical properties of the sediment. As a result, 44 amphipods species were identified. The high number of species found in a relatively limited area highlighted the richness of the Alboran Sea fauna, which is mainly due to the mixture of species from different biogeographic areas. Harpinia genus was the dominant amphipod taxa inside marine caves and Perioculodes longimanus was also very abundant in the caverns. On the other hand, external communities were dominated by Siphonoecetes sabatieri, Metaphoxus fultoni and Photis longipes. There was a high degree of variability in both the internal and the external stations. Only the external station situated at low-medium depth showed a relatively homogeneous amphipod assemblage. The structure and behaviour of soft-bottom communities inside marine caves is difficult to predict because their environmental conditions depend on a particular combination of factors such as topography, depth and orientation. Therefore, no constant patterns were observed for species richness, Shannon diversity and abundance of amphipods in marine caves in comparison with open habitats. According to canonical correspondence analysis, sediment granulometry, organic matter and nitrogen concentration were the parameters that best explained the distribution of amphipods. Species were also classified by their tolerance to environmental pollution according to criteria followed by the Azti Marine Biotic Index and the BENTIX index. The great abundance of sensitive species at both the internal and external stations indicates the good ecological quality of the soft bottom studied. However, the suitability of biotic indices in marine caves should be tested in future studies.
\end{abstract}

Keywords: marine caves; soft-bottom communities; Amphipoda; benthic ecology; Mediterranean Sea.

Anfípodos en sedimentos de cuevas submarinas del Sur de la Península Ibérica: diversidad y distribución ecológica

Resumen: En el presente trabajo se estudia la fauna de anfípodos presente en el sustrato blando de seis cuevas submarinas de la costa Mediterránea del sur de España. Con el objetivo de caracterizar tanto la comunidad biótica como las características físico-químicas del sedimento, se tomaron muestras de sedimento a la salida y en el interior de las cuevas submarinas. Como resultado, se identificaron un total de cuarenta y cuatro especies de anfípodos diferentes. Este elevado número de especies encontrado en un área relativamente limitada pone de manifiesto la riqueza faunística del Mar de Alborán, la cual se atribuye principalmente a la mezcla de especies de diferentes áreas biogeográficas. El género Harpinia fue el taxón dominante en el interior de las cuevas, junto con Perioculodes longimanus. Por otro lado, la comunidad en las zonas externas estaba dominada por Siphonoecetes sabatieri, Metaphoxus fultoni y Photis longipes. Se observó un alto grado de variabilidad tanto en las estaciones internas como externas. Solo las estaciones externas situadas a profundidades bajas-medias mostraron una fauna relativamente homogénea. La estructura y el comportamiento de las comunidades que habitan los sustratos blandos en el interior de cuevas submarinas es difícil de predecir, ya que las condiciones ambientales dependen de sus particulares características en cuanto a topografía, profundidad y orientación. Por ello, no ha podido extraerse ningún patrón constante de la comparación de comunidades internas y externas para el número de especies, diversidad de Shannon o abundancia de anfípodos. La granulometría y los porcentajes de materia orgánica y nitrógeno en el sedimento fueron los parámetros que mejor explicaban la distribución de los anfípodos, de acuerdo con los resultados del análisis CCA. Las especies también fueron clasificadas en base a su tolerancia a la polución ambiental, siguiendo los criterios establecidos por los índices AMBI y BENTIX. La gran abundancia de especies sensibles refleja el buen estado ecológico de los sedimentos estudiados. Sin embargo, la aplicabilidad de los índices bióticos en cuevas submarinas debería ser testada en futuros estudios.

Palabras clave: cuevas submarinas; comunidades de sustrato blando; Amphipoda; ecología bentónica, mar Mediterráneo.

Citation/Como citar este artículo: Navarro-Barranco C., Guerra-García J.M., Sánchez-Tocino L., García-Gómez J.C. 2014. Amphipods from marine cave sediments of the southern Iberian Peninsula: diversity and ecological distribution. Sci. Mar. 78(3): 415-424. doi: http://dx.doi.org/10.3989/scimar.04043.28E

Editor: J.S. Troncoso. 
Received: February 25, 2014. Accepted: May 28, 2014. Published: July 28, 2014.

Copyright: (C) 2014 CSIC. This is an open-access article distributed under the Creative Commons Attribution-Non Commercial Lisence (by-nc) Spain 3.0.

\section{INTRODUCTION}

Marine caves support diverse and distinctive communities, often acting as biodiversity reservoirs for many marine groups (Riedl 1966, Gerovasileiou and Voutsiadou 2012). Because of the importance and peculiarity of these communities, marine caves are also an interesting environment to conduct biological studies. However, in the last few years there has been an increase in the evidence of impact by human activities on cave communities, including alterations by scuba diving activities, coastal pollution and global warming (Chevaldonné and Lejeusne 2003, Di Franco et al. 2010, Parravicini et al. 2010, Guarnieri et al. 2012). Owing to their high natural stability, these ecosystems show low resilience and a high vulnerability to disturbances (Vacelet et al. 1994), so they are considered as priority conservation areas according to Directive 92/43/EEC of the European Community and there is an urgent need to understand their biodiversity and organization. Though many ecological and taxonomical studies have been conducted in marine caves, their soft-bottom communities have often been overlooked. The sediment assemblages inhabiting marine caves often show a distinctive species composition and usually hold many new and endemic species (Bamber et al. 2008; Horton 2008). Within them, crustaceans (and mainly amphipods) are the dominant taxa in both abundance and number of individuals (NavarroBarranco et al. 2012).

In recent years, and especially since the establishment of the European Water Framework Directive (WFD), many biotic indices for evaluating the environmental quality of estuarine and coastal waters have been developed. To evaluate the suitability of these biotic indices it is necessary to test their effectiveness in different regions and environments, and against different types of impact (Diaz et al. 2004, Borja et al. 2009). They have not yet been tested in marine caves.

Given the sensitivity of most amphipods to different kinds of pollution, their abundance, their ecological importance, their relatively low mobility and their close relation with the sediment, they are often considered as good ecological indicators (Gómez-Gesteira and Dauvin 2000, Guerra-García and García-Gómez 2001, dela-Ossa-Carretero et al. 2011). They are therefore used by many indices (e.g. AMBI, BENTIX, MEDOCC and BOPA) to establish the environmental quality of coastal soft-bottom communities (Borja et al. 2000, Simboura and Zenetos 2002, Pinedo and Jordana 2007, Dauvin and Ruellet 2007). However, it is essential to know the environmental preferences and tolerances of each taxon, as discrepancies about the assignation of the same species to different ecological groups contribute to variations in the results obtained with each index (de-la-Ossa-Carretero et al. 2011, Pinedo et al. 2012). Marine caves are therefore suitable places to conduct these studies, since small-scale topographic variability within them generates sharp environmental gradients, allowing a great spatial heterogeneity of environmental conditions and benthic assemblages.

Finally, the patterns in presence of taxa among different marine caves are also of great biogeographic interest. Marine caves are usually considered as islands supporting isolated populations. The existence of species with disjunct distributions in distant marine caves raises questions about how these species can keep their metapopulation dynamics. It has been suggested that a stepping stones model, with larvae moving passively from one cryptic habitat to another, was plausible for some cases (Manconi et al. 2006, 2009). Recent discoveries highlight that these cave-exclusive species are often deepwater species that have denser populations in bathyal areas but are also able to colonize shallow cavernicolous habitats (Bakran-Petricioli et al. 2007). All these aspects have often been investigated in taxa with free-swimming larvae such as sponges and bryozoans (Vacelet et al. 1994, Harmelin 1997). Organisms with a direct development and relatively low dispersion capabilities, such as amphipods, can be expected to show different patterns. All previous studies of peracarid crustaceans of marine caves correspond to taxonomic studies focusing on single marine caves. Therefore, the ability of amphipods to colonize these habitats and the extent to which marine caves are isolated habitats for these organisms with low mobility have not been tested yet.

The main objective of this article is to study the whole soft-bottom amphipod community from submarines caves of southern Spain in order to characterize their unexplored diversity, their distributional patterns and their environmental requirements.

\section{MATERIALS AND METHODS}

\section{Study site and sampling collection}

Our study locations were situated along the coast of Granada (Mediterranean coast of southern Spain). This area is characterized by the abundance of cliffs composed of carbonate rocks, which allow the presence of many marine caves. Six caves were studied: Cueva de Calahonda $\left(36^{\circ} 42^{\prime} 46^{\prime \prime} \mathrm{N}, 3^{\circ} 22^{\prime} 18^{\prime \prime} \mathrm{W}\right)$, Cueva de la Punta del Vapor (36 43'22'”N, $3^{\circ} 42^{\prime} 35^{\prime}$ 'W), Raja de la Mona (36 $\left.43^{\prime} 10^{\prime \prime} \mathrm{N}, 3^{\circ} 44^{\prime} 6^{\prime \prime} \mathrm{W}\right)$, Cueva de los Treinta Metros (36 $\left.43^{\prime} 12^{\prime \prime} \mathrm{N}, 3^{\circ} 44^{\prime} 9^{\prime \prime} \mathrm{W}\right)$, Cueva de Cantarriján $\left(36^{\circ} 44^{\prime} 16^{\prime \prime} \mathrm{N}, 3^{\circ} 46^{\prime} 41^{\prime \prime} \mathrm{W}\right)$ and Cueva de las Gorgonias (36 $44^{\circ} 17^{\prime \prime} \mathrm{N}, 46^{\circ} 46^{\prime} 42^{\prime \prime} \mathrm{W}$ ) (see also Navarro-Barranco et al. 2013). All of them show a similar topographic profile, with a single submerged entrance followed by a rectilinear blind-ending tunnel. These locations comprise a wide range of depth (from 6 to $32 \mathrm{~m}$ deep) and a heterogeneous granulometry (from coarse sand to predominantly muddy sediments).

During July and August 2011, two stations were established and sampled at each location, one inside 
the cave and one in the exterior area (each one approximately $10 \mathrm{~m}$ from the cave entrance). Seven replicate samples were taken at each station using a hand-held rectangular core of $0.025 \mathrm{~m}^{2}$ to a depth of $10 \mathrm{~cm}$ by SCUBA diving. Three of these samples were immediately frozen for physicochemical characterization of each station. Granulometric parameters were determined following the methodology proposed by Guitián and Carballas (1976). Organic matter and major, minor and trace element concentrations in sediments were determined following the methodology presented in Navarro-Barranco et al. (2012). Four replicate samples were used for the biological study of the soft-bottom community. Samples were sieved through a $0.5-\mathrm{mm}$ mesh sieve and preserved in $70 \%$ ethanol stained with Rose Bengal. In the laboratory, all amphipod species were sorted, counted and identified to species level when possible using binocular microscopes.

\section{Data analysis}

Mean values \pm standard deviation (SD) of number of species, total abundance, Shannon-Wiener diversity index (Shannon-Weaver 1963) and abundance of each amphipod species were calculated for each station. Differences between external and internal stations for these indices were tested using an analysis of variance (ANOVA) with two factors: Position (Po) and Site (Si). Po was a fixed factor with two levels (internal and external stations). Si was a fixed factor, orthogonal with Po, with six levels (each marine cave). Four samples were considered in each position $(n=4)$. Prior to analysis, homogeneity of variances was checked using Cochran's test and transformations were applied when necessary (Underwood 1997). A preliminary correlation analysis was done to determine which chemical variables were highly correlated with each other $(\mathrm{p}<0.05)$ and these were eliminated from later analyses to reduce the number of variables considered. Correlation analyses were also done to evaluate the relationship between environmental (depth, granulometry and chemical data) and biological variables (abundance, species richness and Shannon diversity). A permutational analysis of multivariate dispersions (PERMDISP) was carried out to test differences in the variation of the amphipod community between internal and external habitats. Finally, the relationships between environmental variables and the amphipod species were explored by a canonical

\begin{tabular}{|c|c|c|c|c|c|c|c|c|c|c|c|c|c|}
\hline \multirow{2}{*}{ Families } & \multirow[t]{2}{*}{ Species } & \multicolumn{2}{|c|}{ GORGONIAS } & \multicolumn{2}{|c|}{ CANTARRIJAN } & \multicolumn{2}{|c|}{ PTA VAPOR } & \multicolumn{2}{|c|}{ CALAHONDA } & \multicolumn{2}{|c|}{30 METROS } & \multicolumn{2}{|c|}{ RAJA MONA } \\
\hline & & Interior & Exterior & Interior & Exterior & Interior & Exterior & Interior & Exterior & Interior & Exterior & Interior & Exterior \\
\hline \multirow{4}{*}{$\begin{array}{l}\text { Acidostomatidae } \\
\text { Ampeliscidae }\end{array}$} & Acidostoma obesusm & & & & & & & & & & & & \\
\hline & Ampelisca brevicornis & & & & & & & & & & & & \\
\hline & Ampelisca typica & & & & & & & & & & & & \\
\hline & Ampelisca sp. & & & & & & & & & & & & \\
\hline Amphilochidae & Gitana sarsi & & & & & & & & & & & & \\
\hline \multirow{3}{*}{ Aoridae } & Autonoe spiniventris & & & & & & & & & & & & \\
\hline & Lembos sp. & & & & & & & & & & & & \\
\hline & Microdeutopus algicola & & & & & & & & & & & & \\
\hline \multirow[t]{2}{*}{ Bathyporeiidae } & Bathyporeia guilliamsoniana & & & & & & & & & & & & \\
\hline & Bathyporeia sp. & & & & & & & & & & & & \\
\hline \multirow[t]{3}{*}{ Caprellidae } & Pariambus tipicus & & & & & & & & & & & & \\
\hline & Phtisica marina & & & & & & & & & & & & \\
\hline & Pseudolirius kroyeri & & & & & & & & & & & & \\
\hline \multirow{3}{*}{ Corophiidae } & Corophium sp. & & & & & & & & & & & & \\
\hline & Leptocheirus hirsutimanus & & & & & & & & & & & & \\
\hline & Leptocheirus pectinatus & & & & & & & & & & & & \\
\hline Dexaminidae & Guernea coalita & & & & & & & & & & & & \\
\hline \multirow[t]{2}{*}{ Ischyroceridae } & Jassa sp. & & & & & & & & & & & & \\
\hline & Siphonoecetes sabatieri & & & & & & & & & & & & \\
\hline Leucothoidae & Leucothoe sp. & & & & & & & & & & & & \\
\hline \multirow{2}{*}{ Liljeborgiidae } & Liljeborgia sp. & & & & & & & & & & & & \\
\hline & Idunella sp. & & & & & & & & & & & & \\
\hline \multirow[t]{4}{*}{ Lysianassidae } & Hippomedon massiliensis & & & & & & & & & & & & \\
\hline & Lepidepecreum longicornis & & & & & & & & & & & & \\
\hline & Lysianassa sp. & & & & & & & & & & & & \\
\hline & Tryphosella simillima & & & & & & & & & & & & \\
\hline \multirow[t]{2}{*}{ Megaluropidae } & Megaluropus monasteriensis & & & & & & & & & & & & \\
\hline & cf Melita sp. & & & & & & & & & & & & \\
\hline Microprotopidae & Microprotopus maculatus & & & & & & & & & & & & \\
\hline Nuuanuidae & Gammarella fucicola & & & & & & & & & & & & \\
\hline \multirow[t]{4}{*}{ Oedicerotidae } & Deflexilodes griseus & & & & & & & & & & & & \\
\hline & Perioculodes longimanus & & & & & & & & & & & & \\
\hline & Pontocrates arenarius & & & & & & & & & & & & \\
\hline & Synchelidium haplocheles & & & & & & & & & & & & \\
\hline \multirow{8}{*}{$\begin{array}{l}\text { Pontogeneiidae } \\
\text { Photidae } \\
\text { Phoxocephalidae }\end{array}$} & Eusiroides dellavallei & & & & & & & & & & & & \\
\hline & Photis longipes & & & & & & & & & & & & \\
\hline & Harpinia antennaria & & & & & & & & & & & & \\
\hline & Harpinia ala & & & & & & & & & & & & \\
\hline & Harpinia crenulata & & & & & & & & & & & & \\
\hline & Harpinia pectinata & & & & & & & & & & & & \\
\hline & Harpinia sp. & & & & & & & & & & & & \\
\hline & Metaphoxus fultoni & & & & & & & & & & & & \\
\hline Stenothoidae & Stenothoe sp. & & & & & & & & & & & & \\
\hline Urothoidae & Urothoe elegans & & & & & & & & & & & & \\
\hline
\end{tabular}

Fig. 1. - Mean abundance (ind $/ \mathrm{m}^{2}$ ) of the amphipod species at each sampling station. 
Table 1. - Results of the two-factor ANOVA for abundance of individuals, species richness and Shannon-Wiener diversity. No transformations were necessary for diversity and abundance values. Species richness data were Ln(x) transformed; df, degrees of freedom; MS, mean square; $\mathrm{p}$, level of significance; **, $\mathrm{p}<0.01 ; * * *, \mathrm{p}<0.001$.

\begin{tabular}{|c|c|c|c|c|c|c|c|c|c|c|}
\hline \multirow[b]{2}{*}{ Source of variation } & \multirow[b]{2}{*}{ df } & \multicolumn{3}{|c|}{ Abundance } & \multicolumn{3}{|c|}{ Species richness } & \multicolumn{3}{|c|}{ Shannon diversity } \\
\hline & & MS & $\mathrm{F}$ & $\mathrm{p}$ & MS & $\mathrm{F}$ & $\mathrm{p}$ & MS & $\mathrm{F}$ & $\mathrm{p}$ \\
\hline Position $=\mathrm{Po}$ & 1 & 223996.7 & 71.71 & $0.000 * * *$ & 4.83 & 47.71 & $0.000 * * *$ & 1.53 & 10.25 & $0.003 * *$ \\
\hline Site $=\mathrm{Si}$ & 5 & 8468.4 & 27.11 & $0.000 * * *$ & 0.71 & 6.98 & $0.000 * * *$ & 1.07 & 7.19 & $0.000 * * *$ \\
\hline $\mathrm{Po} \times \mathrm{Si}$ & 5 & 125268.1 & 40.10 & $0.000 * * *$ & 0.51 & 4.98 & $0.001 * *$ & 1.27 & 8.50 & $0.000 * * *$ \\
\hline Residual & 36 & 3123.7 & & & 0.10 & & & 0.15 & & \\
\hline
\end{tabular}

correspondence analysis (CCA). The species with very low abundances (those with five or fewer individuals) were not included in the analysis.

Univariate analyses were performed using the GMAV5 program (Underwood et al. 2002) for ANOVA and the SPSS.15 program for the correlations. CCA was carried out using the PC-ORD program (McCune and Mefford 1997), and the PRIMER v.6 + PERMANOVA package (Clarke and Gorley 2001) was used for PERMDISP.

Species were classified in ecological groups in function of their sensitivity to contamination, following the criteria of the Azti Marine Biotic Index (AMBI) and the BENTIX index and classification lists (Borja et al. 2000, Simboura and Zenetos, 2002). Both indices are among the most widely used and require classification to species level. AMBI is the most applied index and classifies the amphipods into three groups: sensitive, indifferent and tolerant species. On the other hand, BENTIX is a biotic index specifically designed for the Mediterranean Sea and only discriminates between sensitive and tolerant species, including the indifferent species (those always present in low densities and with no significant variations in time) in the sensitive group. The percentage of species belonging to each group was calculated for internal and external stations.

Species were also assigned to different biogeographic regions on the basis of information and classifications in Ruffo (1982-1998), Conradi and López-González (1999), Guerra-García et al. (2009) and the World Register of Marine Species (WoRMS) (www.marinespecies.org). The following groups were established:

Mediterranean endemic

Mediterranean and Atlantic Ocean

Mediterranean, Atlantic and Indo-Pacific Ocean

Mediterranean, Atlantic and Arctic Ocean

Cosmopolitan

\section{RESULTS}

Forty-four different species were found in the whole study, belonging to 36 genera and 21 families (Fig. 1). At the external stations, amphipod assemblages were greatly dominated by Siphonoecetes sabatieri de Rouville, 1894, which comprised $68 \%$ of all individuals. The second most dominant species, Metaphoxus fultoni (Scott, 1890), showed much lower abundances, with $5 \%$ of the individuals. Inside the caves, the community was dominated by the genus Harpinia. Four of the seven most abundant species belongs to this genus: $H$. pectinata Sars, 1891, H. crenulata (Boeck, 1871), $H$. antennaria Meinert, 1890 and H. ala Karaman, 1987,
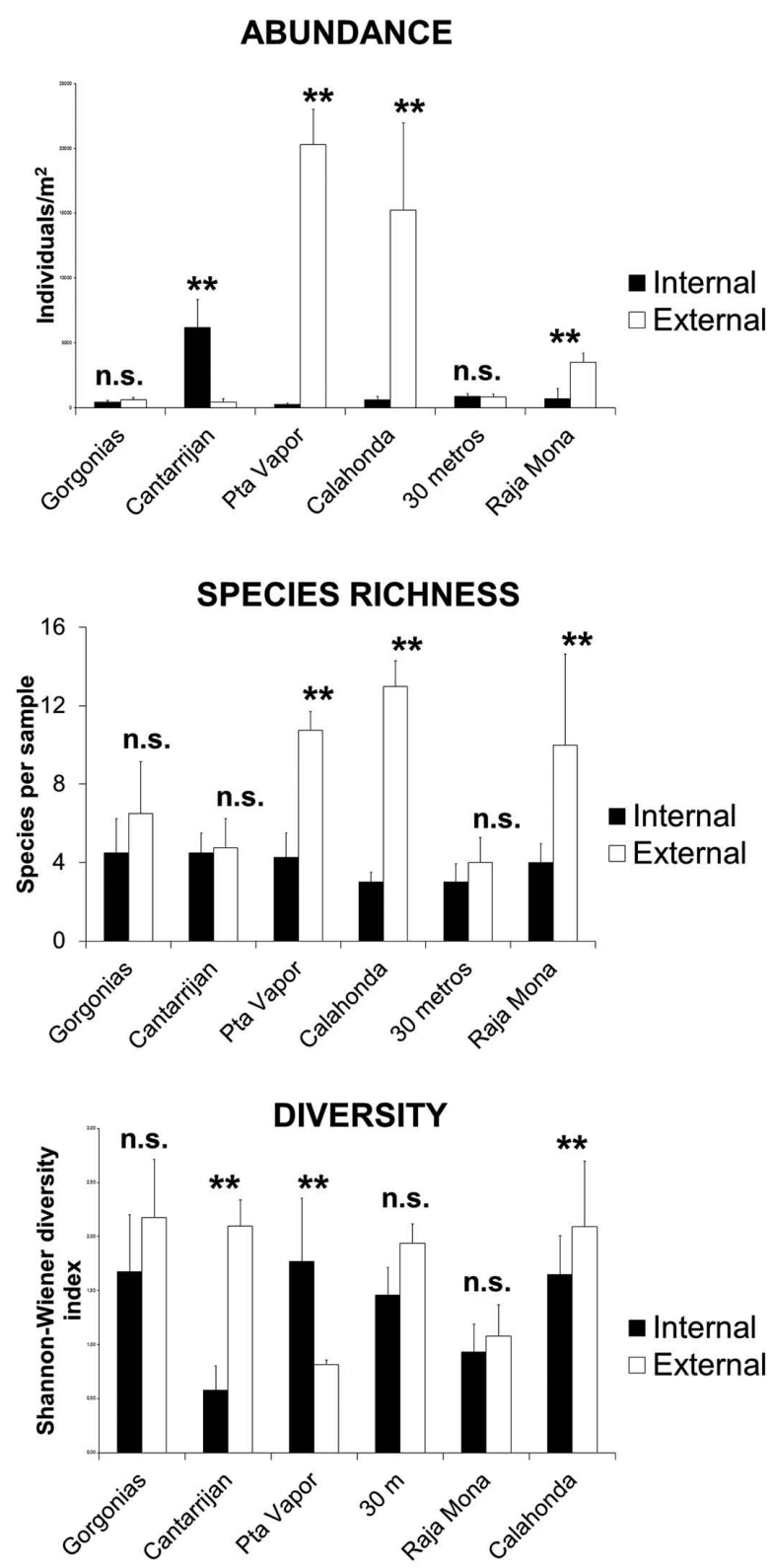

Fig. 2. - Mean values \pm SD of abundance of individuals, number of species and Shannon-Wiener diversity index for each sampling station. Significance of differences between positions is also represented. **, $\mathrm{p}<0.01 ;$ n.s., non significant.

in order of importance. Perioculodes longimanus (Bate and Westwood, 1868), with $20 \%$ of the individuals, was also very abundant at the internal stations.

According to univariate analyses, there were significant differences between external and internal stations in abundance, species richness and diversity (Fig. 
Table 2. - Depth and mean values obtained for sediment variables at each sampling station. OM, organic matter. Depth was measured in meters, $\mathrm{OM}$ and $\mathrm{N}$ in percentage and the rest of elements in $\mathrm{mg} / \mathrm{kg}$.

\begin{tabular}{|c|c|c|c|c|c|c|c|c|c|c|c|c|c|c|}
\hline & & $\operatorname{Depth}(\mathrm{m})$ & $\mathrm{OM}(\%)$ & $\mathrm{N}(\%)$ & $\mathrm{Al}$ & As & B & $\mathrm{Ba}$ & $\mathrm{Ca}$ & $\mathrm{Cd}$ & $\mathrm{Co}$ & $\mathrm{Cr}$ & $\mathrm{Cu}$ & $\mathrm{Fe}$ \\
\hline \multirow[t]{2}{*}{ Gorgonias } & Internal & 6 & 0.84 & 0.04 & 18182.04 & 5.48 & 12.34 & 71.09 & 82963.75 & 0.10 & 8.37 & 24.48 & 12.15 & 18508.70 \\
\hline & External & 6 & 0.23 & 0.01 & 16669.01 & 4.58 & 3.93 & 61.91 & 49322.88 & 0.04 & 8.36 & 23.74 & 9.73 & 19074.20 \\
\hline \multirow[t]{2}{*}{ Cantarriján } & Internal & 8 & 0.74 & 0.02 & 18055.49 & 4.93 & 7.26 & 66.72 & 58619.00 & 0.17 & 8.64 & 24.94 & 12.31 & 19826.50 \\
\hline & External & 8 & 0.18 & 0.01 & 13712.99 & 4.72 & 3.06 & 42.09 & 47420.27 & 0.05 & 8.54 & 21.88 & 11.37 & 19404.90 \\
\hline \multirow[t]{2}{*}{ Pta. Vapor } & Internal & 12 & 0.76 & 0.05 & 24960.49 & 7.26 & 13.85 & 150.46 & 79923.38 & 0.06 & 13.66 & 43.98 & 15.39 & 29750.81 \\
\hline & External & 12 & 0.44 & 0.02 & 26043.12 & 5.65 & 7.11 & 172.97 & 53089.43 & 0.04 & 14.41 & 49.91 & 11.68 & 32208.23 \\
\hline \multirow[t]{2}{*}{ Calahonda } & Internal & 19 & 0.98 & 0.07 & 17663.12 & 7.39 & 10.77 & 41.82 & 60199.82 & 0.10 & 10.47 & 21.55 & 17.42 & 25212.95 \\
\hline & External & 19 & 0.40 & 0.03 & 6591.39 & 7.18 & 8.23 & 10.82 & 81739.77 & 0.11 & 7.00 & 9.73 & 7.86 & 17163.00 \\
\hline \multirow{2}{*}{ Treinta Metros } & Internal & 30 & 1.86 & 0.12 & 25053.40 & 7.88 & 21.50 & 91.95 & 71626.79 & 0.14 & 11.27 & 35.18 & 19.02 & 25701.81 \\
\hline & External & 30 & 1.95 & 0.17 & 25902.39 & 7.28 & 17.17 & 61.46 & 67604.02 & 0.24 & 10.38 & 28.37 & 10.10 & 4456.48 \\
\hline \multirow[t]{3}{*}{ Raja Mona } & Internal & 32 & 0.79 & 0.08 & 3822.23 & 3.34 & 41.35 & 24.42 & 289776.85 & 0.23 & 1.77 & 6.12 & 9.81 & 4139.20 \\
\hline & External & 32 & 0.56 & 0.04 & 2834.40 & 3.41 & 43.64 & 22.33 & 303190.25 & 0.23 & 1.17 & 4.76 & 2.75 & 3374.96 \\
\hline & & $\operatorname{Depth}(\mathrm{m})$ & K & $\mathrm{Li}$ & $\mathrm{Mn}$ & $\mathrm{Na}$ & $\mathrm{Ni}$ & $\mathrm{P}$ & $\mathrm{Pb}$ & S & $\mathrm{Sr}$ & V & $\mathrm{Zn}$ & \\
\hline \multirow[t]{2}{*}{ Gorgonias } & Internal & 6 & 5975.69 & 19.93 & 249.14 & 6003.37 & 17.02 & 448.49 & 9.27 & 1400.19 & 513.62 & 41.06 & 41.39 & \\
\hline & External & 6 & 4526.50 & 18.02 & 253.69 & 3144.54 & 15.64 & 281.04 & 8.39 & 420.12 & 165.68 & 39.23 & 32.40 & \\
\hline \multirow[t]{2}{*}{ Cantarriján } & Internal & 8 & 5336.79 & 18.73 & 261.27 & 4728.77 & 16.78 & 363.08 & 8.77 & 837.93 & 244.49 & 42.18 & 38.26 & \\
\hline & External & 8 & 3385.46 & 15.73 & 236.45 & 2914.77 & 17.42 & 283.52 & 9.63 & 347.02 & 141.56 & 35.92 & 37.02 & \\
\hline \multirow{2}{*}{ Pta. Vapor } & Internal & 12 & 9896.94 & 21.78 & 426.01 & 4819.90 & 27.59 & 639.36 & 11.94 & 1582.53 & 611.31 & 65.18 & 90.92 & \\
\hline & External & 12 & 10845.45 & 20.76 & 406.45 & 3609.38 & 27.63 & 408.11 & 7.81 & 818.66 & 427.42 & 70.55 & 65.29 & \\
\hline \multirow[t]{2}{*}{ Calahonda } & Internal & 19 & 3759.01 & 33.44 & 263.56 & 5443.29 & 24.09 & 778.70 & 16.36 & 1140.75 & 342.73 & 38.75 & 75.40 & \\
\hline & External & 19 & 1401.77 & 16.13 & 200.43 & 4755.77 & 17.19 & 506.33 & 9.05 & 999.94 & 579.19 & 22.38 & 44.03 & \\
\hline \multirow[t]{2}{*}{ Treinta Metros } & Internal & 30 & 7746.73 & 30.80 & 279.39 & 7011.72 & 27.02 & 786.90 & 18.56 & 2049.61 & 523.70 & 54.44 & 79.19 & \\
\hline & External & 30 & 5867.30 & 20.12 & 205.02 & 8306.28 & 20.00 & 579.36 & 15.38 & 3294.29 & 865.00 & 54.13 & 65.21 & \\
\hline \multirow{2}{*}{ Raja Mona } & Internal & 32 & 2047.58 & 5.46 & 105.88 & 6642.80 & 5.32 & 545.62 & 7.97 & 4071.12 & 3248.41 & 10.48 & 25.53 & \\
\hline & External & 32 & 1779.27 & 4.24 & 102.48 & 8241.84 & 4.23 & 570.48 & 8.39 & 3895.80 & 3774.16 & 8.36 & 24.32 & \\
\hline
\end{tabular}

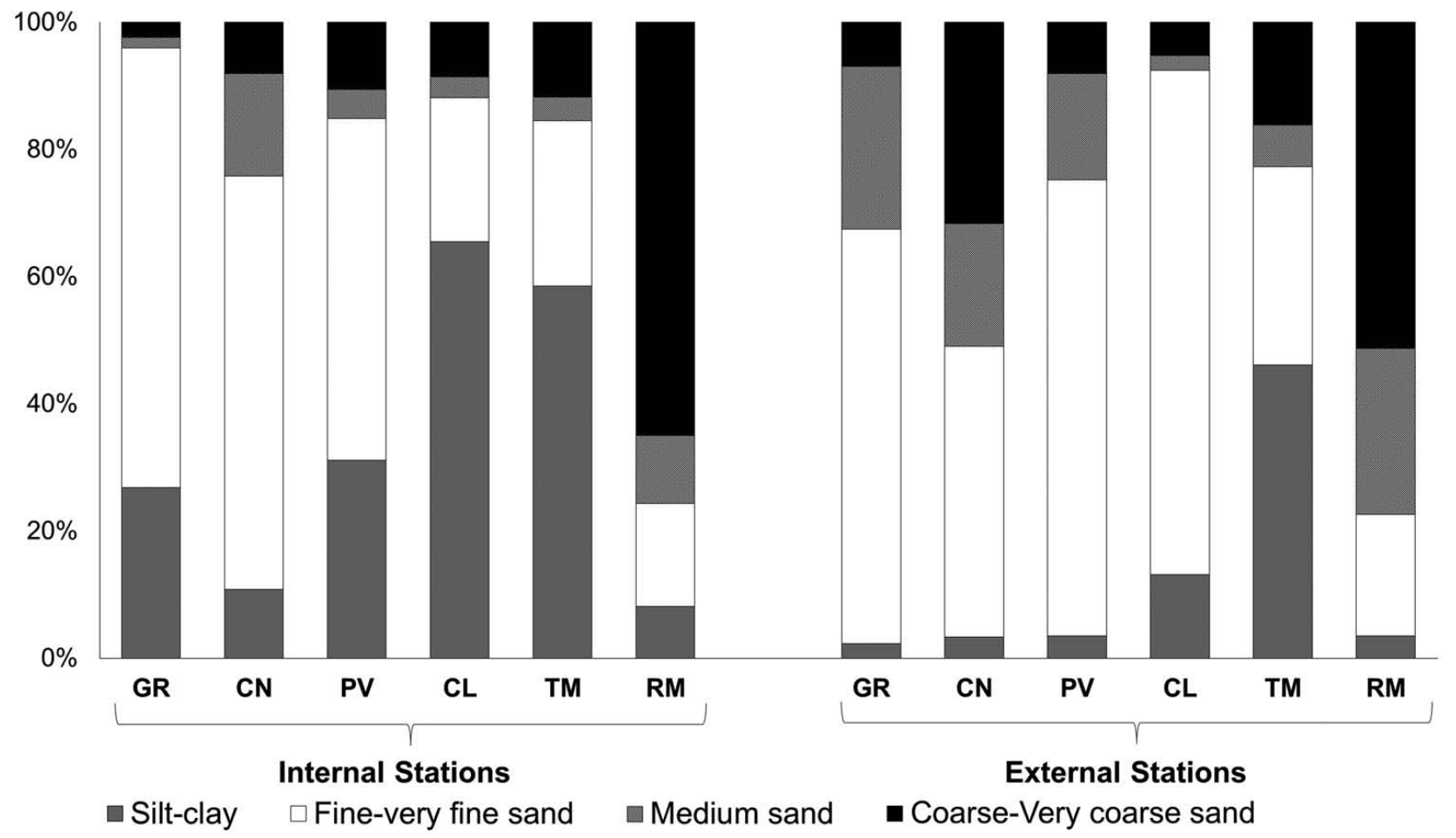

Fig. 3. - Percentage of the different granulometric fractions at each sampling station.

2, Table 1). Although external stations often showed higher values in these parameters, no constant pattern was observed and ANOVA also determined that the factor Site and the interaction between the two factors $(\mathrm{Po} \times \mathrm{Si})$ were significant (Table 1$)$. However, the differences between positions were not significant for all the stations, and at some of them we found the opposite pattern, with higher values at the internal stations.
The results of physicochemical variables are summarized in Table 2 and Figure 3. Correlation analyses conducted with chemical analysis helped to reduce the number of variables from 23 to 7 : organic matter, $\mathrm{P}$, $\mathrm{N}, \mathrm{Cu}, \mathrm{Pb}, \mathrm{S}$ and $\mathrm{Cr}$. $\mathrm{Pb}$ had a significant correlation $(\mathrm{p}<0.01)$ with As, Li and Zn. S was correlated $(\mathrm{p}<0.01)$ with $\mathrm{B}, \mathrm{Ca}, \mathrm{Cd}, \mathrm{Na}$ and $\mathrm{Sr}$, while $\mathrm{Cr}$ showed a strong correlation $(\mathrm{p}<0.01)$ with $\mathrm{Al}, \mathrm{N}, \mathrm{Ba}, \mathrm{Co}, \mathrm{Fe}, \mathrm{K}, \mathrm{Mn}$, 


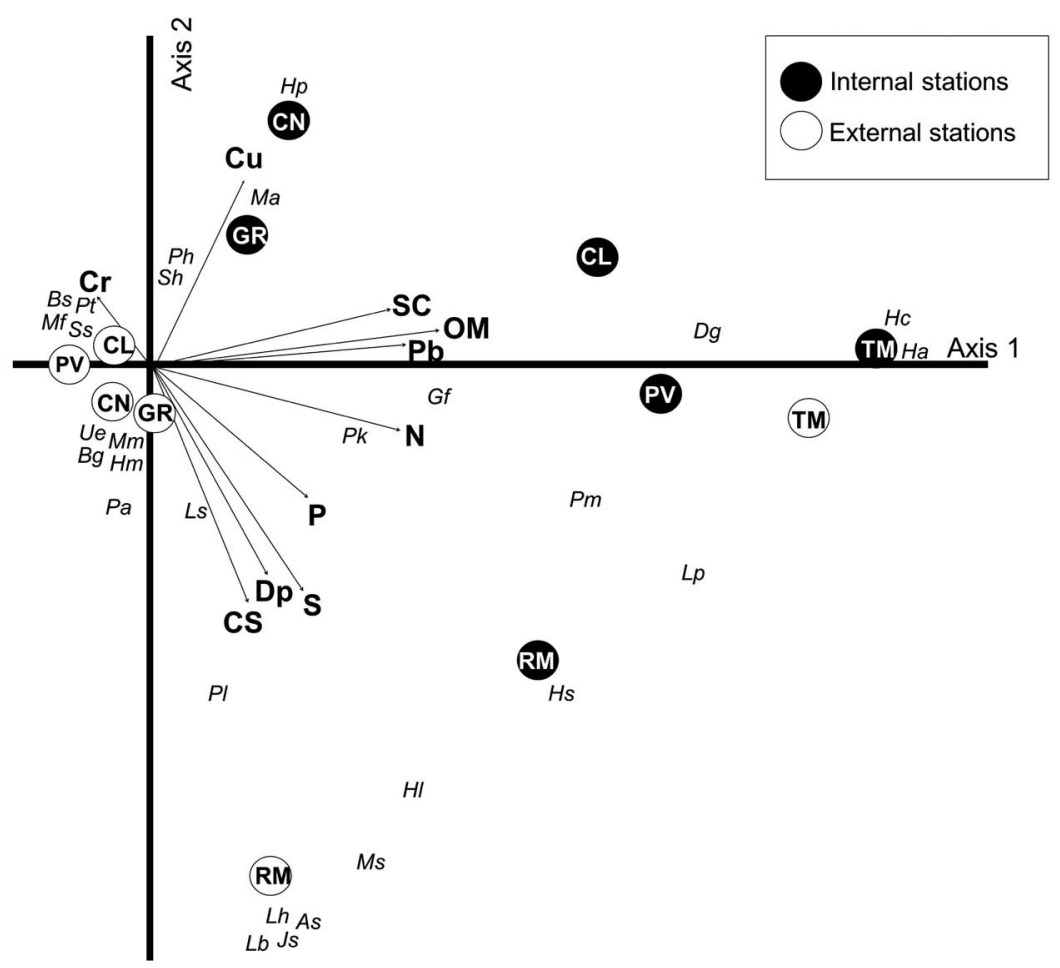

Fig. 4. - Graphic representation of the stations, species and environmental variables with respect to the first two axes of the canonical correspondence analysis (CCA). SC (silt and clay), CS (coarse sand), OM (organic matter), Dp (depth), As (Ampelisca sp.), Bs (Bathyporeia sp.), Bg (Bathyporeia guilliamsoniana), Dg (Deflexilodes griseus), Gf (Gammarella fucicola), Ha (Harpinia antennaria), Hc (Harpinia crenulata), Hp (Hippomedon massiliensis), Hl (Harpinia ala), Hs (Harpinia sp.), Js (Jassa sp.), Lb (Lembos sp.), Lh (Leptocheirus hirsutimanus), Lp (Leptocheirus pectinatus), Ls (Leucothoe sp.), Ma (Microdeutopus algicola), Mf (Metaphoxus fultoni), Mm (Megaluropus monasteriensis), Ms (cf. Melita sp.), Pa (Pontocrates arenarius), Ph (Photis longipes), Pk, (Pseudolirius kroyeri), Pl (Perioculodes longimanus), Pm (Phtisica marina), Pt (Pariambus tipicus), Ss (Siphonoecetes sabatieri), Ue (Urothoe elegans).

$\mathrm{Ni}, \mathrm{V}$ and $\mathrm{Zn}$. There were no significant correlations among the environmental variables and the abundance, species richness and diversity values.

According to CCA results (Fig. 4, Table 3), 59.4\% of the total variation can be explained by measured environmental variables. The eigenvalues obtained for the three axes are fairly high, implying that these axes represent a strong gradient. All the environmental variables used in the analysis correlated significantly with at least one of the three axes. Axis 1 explained $21.1 \%$ of the species variance and was strongly correlated with the percentage of silt and clay, organic matter and nitrogen. The second axis, mainly associated negatively with the percentage of coarse sand and the

Table 3. - Summary of the results of the CCA analysis. Only the variables that correlated with the first three axes were included. *, $\mathrm{p}<0.05 ; * *, \mathrm{p}<0.01 ; * * *, \mathrm{p}<0.001$.

\begin{tabular}{lccc}
\hline & Axis 1 & Axis 2 & Axis 3 \\
\hline Eigenvalue & 0.88 & 0.81 & 0.78 \\
Species-environment correlation & 1 & 1 & 1 \\
Percentage of species variance & 21.1 & 19.5 & 18.8 \\
Correlation with environmental variables & & \\
OM (organic matter) $(\%)$ & $0.90^{* * *}$ & - & $-0.61^{*}$ \\
$\mathrm{~N}(\%)$ & $0.87^{* * *}$ & - & $-0.60^{*}$ \\
$\mathrm{Cr}(\mathrm{mg} / \mathrm{kg})$ & - & - & $-0.55^{*}$ \\
$\mathrm{Cu}(\mathrm{mg} / \mathrm{kg})$ & $0.56^{*}$ & $0.65^{*}$ & $-0.59^{*}$ \\
$\mathrm{P}(\mathrm{mg} / \mathrm{kg})$ & $0.80^{* *}$ & - & - \\
$\mathrm{Pb}(\mathrm{mg} / \mathrm{kg})$ & $0.85^{* *}$ & - & $-0.76^{* *}$ \\
$\mathrm{~S}(\mathrm{mg} / \mathrm{kg})$ & - & $-0.73^{* *}$ & - \\
$\mathrm{CS}(\mathrm{coarse}$ sand) $(\%)$ & - & $-0.82^{* * *}$ & - \\
$\mathrm{SC}(\mathrm{silt}$ and clay) $(\%)$ & $0.82^{* * *}$ & - & $-0.63^{*}$ \\
Depth (m) & $-0.61^{*}$ & $-0.60^{*}$ & - \\
\hline
\end{tabular}

concentration of sulfur, explained $19.5 \%$ of the species variance. The majority of stations, and hence also the species, are fairly separated in the graph (Fig. 4). Only the stations of Gorgonias, Cantarrijan, Punta del Vapor and Calahonda were closer in the graph, while the other two external stations (the deepest ones) were fairly separated. There was no clear separation between internal and external stations. PERMDISP analysis

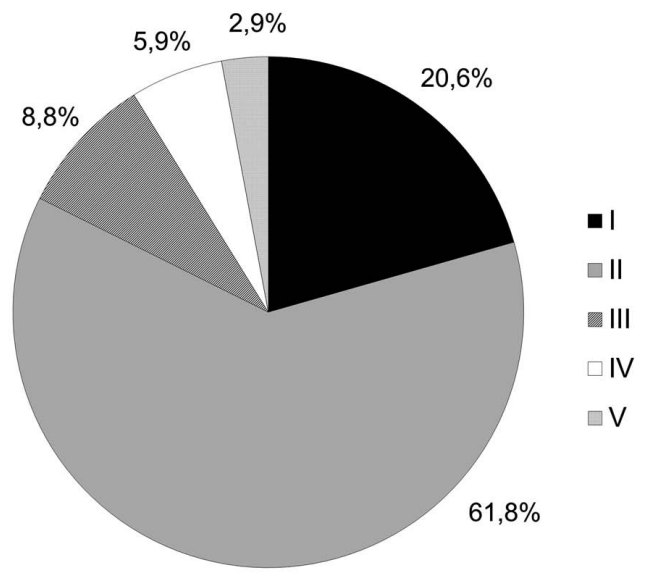

Fig. 5. - Percentage of recorded taxa belonging to the following groups of geographical distribution. I, Mediterranean endemic; II, Mediterranean and Atlantic Ocean; III, Mediterranean, Atlantic and Indo-Pacific Ocean; IV, Mediterranean, Atlantic and Artic Ocean; V, Cosmopolitan. 
AMBI
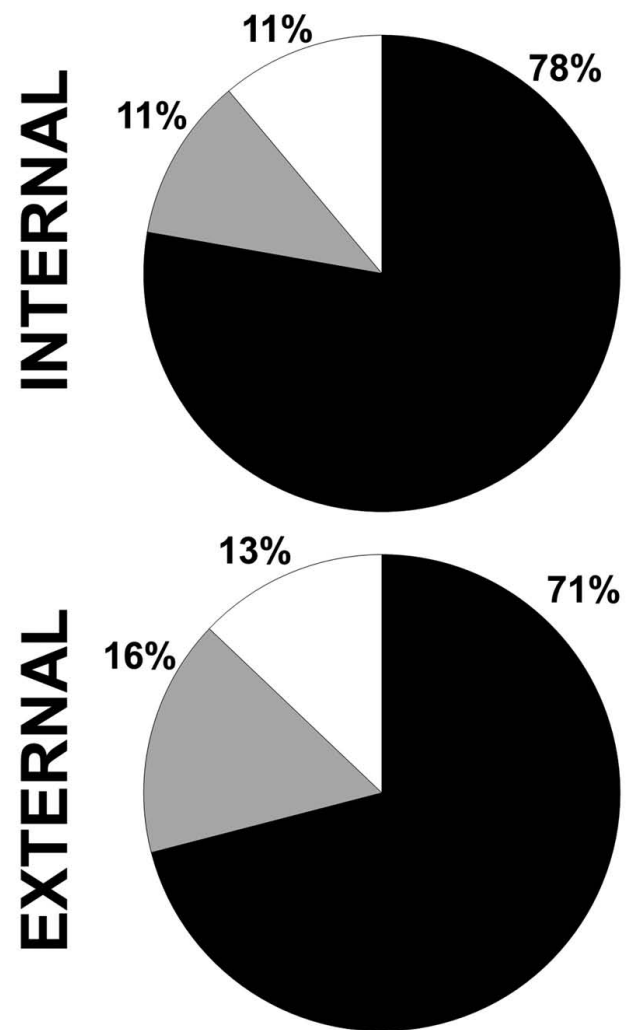

- Sensitive $\square$ Indifferent
BENTIX
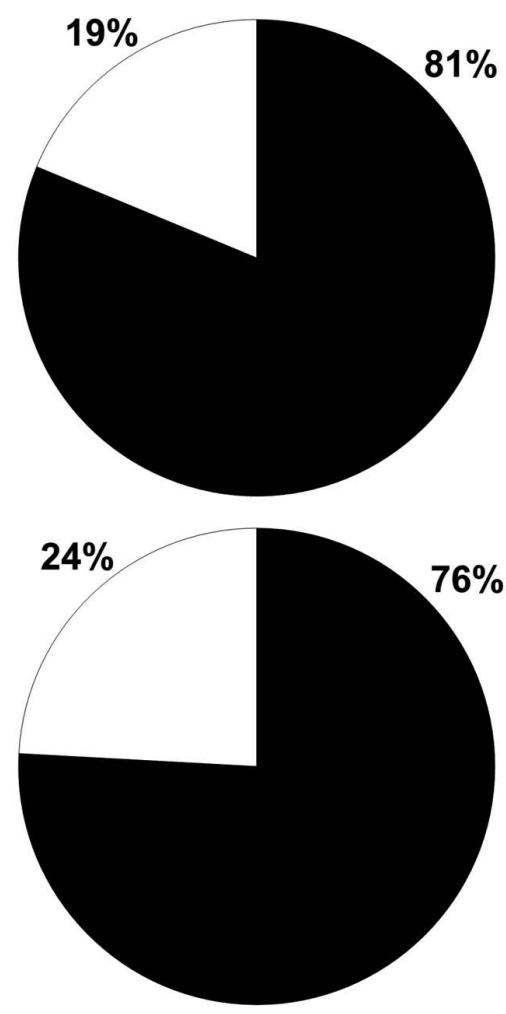

Tolerant

Fig. 6. - Percentage of species belonging to ecological groups in function of their tolerance to environmental pollution.

showed no significant differences in the variability between external and internal stations $(F=0.32 ; p=0.61)$. CCA also showed the existence of some groups of species with a very similar relation to the environmental variables. One of them enclosed the species associated with the shallow and medium-depth external stations, including Siphonoecetes sabatieri, Bathyporeia guilliamsoniana (Bate, 1857), Pariambus tipicus (Krøyer, 1884) and Metaphoxus fultoni. On the other hand, the external station of Raja de la Mona showed a very characteristic community, with many species, such as Jassa sp. and Leptocheirus hirsutimanus (Bate, 1862), only present at this station. Besides being the deepest station, the peculiarity of this sampling point is due to the high percentage of coarse sand and gravels. The rest of the species were dispersed in the graph. Species of the Harpinia genus were always closely associated with internal stations but separated between those with higher abundances in muddy sediments (Harpinia antennaria or Harpinia crenulata) and those present in coarse sands (Harpinia ala and Harpinia sp.).

Species in the Atlantic-Mediterranean group were the majority $(61.8 \%)$, followed by the Mediterranean endemic group (20.6\%) (Fig. 5). The percentage of species belonging to each ecological group showed no great variations between stations, being clearly dominated by sensitive species at both external and internal stations
(Fig. 6). The use of either the AMBI or the BENTIX biotic index does not seem to have a great influence on the results, since in both cases sensitive species were also dominant. However, though BENTIX includes the indifferent species as sensitive, the percentage of tolerant species was higher with this index.

\section{DISCUSSION}

\section{Internal vs external stations}

Traditionally, the diversity impoverishment of cave faunas has been a widely accepted pattern. This fact was explained by the reduced trophic supply inside submarine caves (Zabala et al. 1989, Fichez 1990). However, in recent years quantitative studies conducted simultaneously in different caves have highlighted the difficulty of finding general and consistent patterns in marine cave communities (Bussotti et al. 2006, Navarro-Barranco et al. 2013). In the present study, mean values of abundance, species richness and Shannon diversity were higher at external stations. However, although this trend has been observed in most studies of marine caves, it cannot be considered as a constant pattern. The finer sediments inside caves are often more stable and show a higher concentration of organic matter, often allowing the ex- 
istence of complex and rich soft-bottom communities. For example, internal stations of the Cantarrijan cave showed abundances of amphipods more than ten times higher than external stations because of an unusually high density of Harpinia pectinata. We found another exception to the general pattern in Punta del Vapor, where samples showed lower diversity values at external stations, mainly because of the overwhelming numerical dominance of Siphonoecetes sabatieri. This lack of general patterns is not surprising. Despite their apparent environmental homogeneity, marine caves often show high variability because many complex mechanisms, both physical and biological, structure the soft-bottom communities (e.g. Morrisey et al. 1992, Snelgrove 1998, Norén and Lindegarth 2005). Moreover, each marine cave has particular environmental conditions determined by features such as its topography, depth and orientation. As a result, the behaviour of the soft-bottom communities inside marine caves is difficult to predict.

Most of the species found inside the caves were also present at external stations. Among the species only found at external stations, some of them seemed to show a special avoidance of cave habitats. Siphonoecetes sabatieri, Urothoe elegans (Bate, 1857) and Pontocrates arenarius (Bate, 1858) are some of the species with a wider distribution in the study, being present in most of the sampling areas but with no single individual inside the caves. On the other hand, some species, such as Microdeutopus algicola Della Valle, 1893, Liljeborgia sp. and Gammarella fucicola (Leach, 1814), were only present at internal stations. Anyway, none of the species found in the present study are cave-exclusive, having all been previously cited in open habitats (Ruffo 1982-1998). This is a common feature in marine cave fauna, since most of the species only use the caverns for shelter and can also be found outside the caves in similar habitats (Scipione et al. 1981, Gerovasileiou and Voultsiadou 2012). The genus Harpinia, for example, was found predominantly inside marine caves, but was also present at some external stations, thus facilitating intercommunication among cave assemblages. Therefore, amphipod cave communities are not as isolated as could be expected, and the stepping stones model can probably be used to understand their population dynamics.

\section{Biogeographical considerations}

It was difficult to compare the diversity results obtained in the present study with those found in shallow soft-bottoms habitats of other localities of the Iberian Peninsula, since there is a great variation among studies in the sampling methodology (number of samples, degree of spatial and temporal replication, etc). Studies carried out in the Atlantic zone of the Iberian Peninsula found between 34 and 79 different amphipod species in the northwestern area (Cunha et al. 1999, Lourido et al. 2008, Moreira et al. 2008, Cacabelos et al. 2010) and 93 species on the southern Portuguese coast (Carvalho et al. 2012). On the other hand, in the Mediterranean area, an in- ventory of soft-bottom amphipods from the east coast of the Iberian Peninsula revealed the presence of 55 different species (de-la-Ossa-Carretero et al. 2010). This value is slightly higher than that found in the present work. However, taking into account the huge differences in the sampling effort between these two studies (40 stations along $250 \mathrm{~km}$ of coast were sampled during five consecutive years in the east coast study), the total amphipod species richness in shallow sediments could be expected to be higher in the Alboran Sea area. The relevance and high diversity of the Alboran Sea in comparison with other Mediterranean areas, mainly owing to the overlap of Atlantic and Mediterranean faunas, has already been reported (Guerra-García et al. 2009). In this sense, only in the sediments of Ceuta Harbour and Algeciras Bay (both of them in the Strait of Gibraltar), 44 and 55 amphipod species were collected, respectively, by Conradi and López-Gónzalez (1999) and Guerra-García and García-Gómez (2004). Moreover, the existence of several upwelling areas in the littoral of southern Spain may also contribute to the high biological richness of this area (Delgado 1990).

Most of the species found have a wide range of distribution, present in more than one biogeographical region. However, only one species, Ampelisca brevicornis (Costa, 1853), can be considered cosmopolitan. The percentage of Mediterranean endemism (20.6\%) was similar to that obtained in previous amphipod studies in the Strait of Gibraltar area (Conradi and López-Gónzalez 1999, Guerra-García et al. 2009), but surprisingly higher than that obtained on the east coast of the Iberian Peninsula (12.7\%) (de-la-Ossa-Carretero et al. 2010).

\section{Ecological quality and environmental preferences}

All the variables included in the CCA were significant but sediment granulometry, organic matter and $\mathrm{N}$ concentration were the main parameters explaining the distribution of amphipods; this finding is a common feature in soft-bottom ecology studies (Pearson and Rosenberg 1978, Carvalho et al. 2012).

Regarding the ecological quality of the communities studied, the high abundance of sensitive species indicated the good state of the assemblages. The chemical data obtained agree with that conclusion, since almost all the values at all stations were far below the highest reference values tolerated in marine sediment quality guidelines (Grimwood and Dixon 1997, Long et al. 1998). Thus, because of the lack of polluted stations, it is not possible for us to evaluate the suitability of the indices for detecting the anthropogenic impacts in marine caves. Although axis 1 in the CCA correlated significantly with the concentration of organic matter, $\mathrm{N}, \mathrm{P}, \mathrm{Pb}$ and $\mathrm{Cu}$, this first axis does not represent a pollution gradient, since the concentration of heavy metals and the organic enrichment levels was not very high at any station. The rise in these concentrations is associated with the increase (mainly at internal stations) in the percentage of silt and clay, which have a higher capacity to retain elements. The a priori tolerant spe- 
cies, such as Gammarella fucicola, Pariambus typicus and Leptocheirus hirsutimanus, appear separated in the CCA. However, another way to evaluate the suitability of the indices is to analyse the level of agreement between results obtained by different indices (Borja and Dauer 2008). In this case, both indices showed similar results for the percentage of sensitive species and BENTIX showed slightly higher results for tolerant species. These small differences were due to some discrepancies in the assignment of ecological groups for some species. The caprellid Phtisica marina Slabber, 1769, for example, is classified as tolerant by BENTIX and sensitive by AMBI. The analysis of the ecology of soft-bottom caprellids in Southern Spain carried out by Guerra-García and García-Gómez (2001) and Guerra-García et al. (2012) supports the BENTIX classification, since it is able to tolerate conditions of high organic enrichment and low oxygen concentrations. The gammarid Perioculodes longimanus is considered a tolerant species by AMBI and a sensitive one by BENTIX. P. longimanus was present at most of the stations, regardless of the granulometry, depth or position (external or internal). Its abundance at these stations with high ecological quality was often very high, suggesting that $P$. longimanus should probably be considered an indifferent species in the AMBI's list of species. Other discrepancies between indices occur for the gammarids Pontocrates arenarius, Leptocheirus pectinatus (Norman, 1869) and Microdeutopus algicola. However, since all our stations showed a good state of conservation and some of these species were in very low densities, we were unable to discriminate the tolerance of these species. The study area is subjected to a low anthropogenic influence and some of the caves are even inside a marine protected area (Rodriguez et al. 2003). Future studies involving marine caves with a higher gradient of pollution stress would be very useful to properly evaluate the tolerances of different taxa and the suitability of biotic indices in marine caves.

\section{ACKNOWLEDGEMENTS}

Financial support for this work was provided by the Ministerio de Economía y Competitividad (Project CGL 2011-22474, internal reference 2011-707). It was cofinanced by FEDER funds of the European Union and by the Consejería de Economía, Innovación, Ciencia y Empleo, Junta de Andalucía (Project P11-RNM-7041). Special thanks to Sara Cea and Pablo Jiménez-Prada for their help in the sorting the organisms and to two anonymous reviewers for their very helpful comments. This work is part of C.N-B's PhD thesis, supported by the University of Seville (PIF Grant).

\section{REFERENCES}

Bakran-Petricioli T., Vacelet J., Zibrowius H., et al. 2007. New data on the distribution of the 'deep-sea' sponges Asbestopluma hypogea and Oopsacas minuta in the Mediterranean Sea. Mar. Ecol. 28(1): 10-23. http://dx.doi.org/10.1111/j.1439-0485.2007.00179.x

Bamber R.N., Evans N.J., Robbins R.S. 2008. The marine softsediment benthic communities of Hong Kong: a comparison of submarine cave and open habitats. J. Nat. Hist. 42(9): 953-965. http://dx.doi.org/10.1080/00222930701850604

Borja A., Dauer D.M. 2008. Assessing the environmental quality status in estuarine and coastal systems: comparing methodologies and indices. Ecol. Ind. 8: 331-337. http://dx.doi.org/10.1016/j.ecolind.2007.05.004

Borja A., Franco J., Pérez V. 2000. A marine biotic index to establish the ecological quality of soft-bottom benthos within European estuarine and coastal environments. Mar. Pollut. Bull. 40: 1100-1114. http://dx.doi.org/10.1016/S0025-326X(00)00061-8

Borja A., Miles A., Occhipinti-Ambrogi A., et al. 2009. Current status of macroinvertebrate methods used for assessing the quality of European marine waters: implementing the Water Framework Directive. Hydrobiologia 633: 181-196. http://dx.doi.org/10.1007/s10750-009-9881-y

Bussotti S., Terlizzi A., Fraschetti S., et al. 2006. Spatial and temporal variability of sessile benthos in shallow Mediterranean marine caves. Mar. Ecol. Prog. Ser. 325: 109-119. http://dx.doi.org/10.3354/meps325109

Cacabelos E., Lourido A., Troncoso J.S. 2010. Composition and distribution of subtidal and intertidal crustacean assemblages in soft-bottoms of the Ria de Vigo (NW Spain). Sci. Mar. 74(3): 455-464. http://dx.doi.org/10.3989/scimar.2010.74n3455

Carvalho S., Cunha M.R., Pereira F., et al. 2012. The effect of depth and sediment type on the spatial distribution of shallow softbottom amphipods along the southern Portuguese coast. Helgol. Mar. Res. 66 (4): 489-501. http://dx.doi.org/10.1007/s10152-011-0285-9

Chevaldonné P., Lejeusne C. 2003. Regional warming-induced species shift in north-west Mediterranean marine caves. Ecol. Lett. 6: 371-379. http://dx.doi.org/10.1046/j.1461-0248.2003.00439.x

Clarke K.R., Gorley R.N. 2001. PRIMER (Plymouth Routines in Multivariate Ecological Research) v5: User Manual/Tutorial. PRIMER-E Ltd., Plymouth, 91 pp.

Conradi M., López-Gónzalez P.J. 1999. The benthic Gammaridea (Crustacea, Amphipoda) fauna of Algeciras Bay (Strait of Gibraltar): distributional ecology and some biogeographical considerations. Helgol. Mar. Res. 53: 2-8. http://dx.doi.org/10.1007/PL00012134

Cunha M.R., Sorbe J.C., Moreira M.H. 1999. Spatial and seasonal changes of brackish peracaridan assemblages and their relation to some environmental variables in two tidal channels of the Ria de Aveiro (NW Portugal). Mar. Ecol. Prog. Ser. 190: 69-87. http://dx.doi.org/10.3354/meps190069

Dauvin J.C., Ruellet T. 2007. Polychaete/amphipod ratio revisited. Mar. Pollut. Bull. 55: 215-224. http://dx.doi.org/10.1016/j.marpolbul.2006.08.045

de-la-Ossa-Carretero J.A., Dauvin J.C., Del-Pilar-Ruso Y., et al. 2010. Inventory of benthic amphipods from fine sand community of the Iberian Peninsula east coast (Spain), western Mediterranean, with new records. Mar. Biod. Rec. 3: 1-10.

de-la-Ossa-Carretero J.A., Del-Pilar-Ruso Y., Giménez-Casalduero F., et al. 2011. Sensitivity of amphipods to sewage pollution. Est. Coast. Shelf Sci. 96(1): 129-138.

Delgado M. 1990. Phytoplankton distribution along the Spanish coast of the Alboran Sea. Sci. Mar. 54(2): 169-178.

Diaz R.J., Solan M., Valente R.M. 2004. A review of approaches for classifying benthic habitats and evaluating habitat quality. J. Environ. Manage. 73: 165-181. http://dx.doi.org/10.1016/j.jenvman.2004.06.004

Di Franco A., Milazzo M., Baiata P., et al. 2010. Can recreational scuba divers alter natural gross sedimentation rate? A case study from a Mediterranean deep cave. ICES J. Mar. Sci. 67: 871-874. http://dx.doi.org/10.1093/icesjms/fsq007

Fichez R. 1990. Decrease in allochthonous organic inputs in dark submarine caves, connection with lowering in benthic community richness. Hydrobiologia. 207: 61-69. http://dx.doi.org/10.1007/BF00041441

Gerovasileiou V., Voultsiadou E. 2012. Marine caves of the Mediterranean Sea: a sponge biodiversity reservoir within a biodiversity hotspot. PLoS ONE, 7 (7), e39873. http://dx.doi.org/10.1371/journal.pone.0039873

Gómez-Gesteira J.L., Dauvin J.C. 2000. Amphipods are good bioindicators of the impact of oil spills on soft-bottom macrobenthic communities. Mar. Pollut. Bull. 40: 1017-1027. http://dx.doi.org/10.1016/S0025-326X(00)00046-1

Grimwood M.J., Dixon E. 1997. Assessment of risks posed by List II metals to Sensitive Marine Areas (SMAs) and adequacy of 
existing environmental quality standars (EQSs) for SMA protection. Report to English Nature.

Guarnieri G., Terlizzi A., Bevilacqua S., et al 2012. Increasing heterogeneity of sensitive assemblages as a consequence of human impact in submarine caves. Mar. Biol. 159: 1155-1164. http://dx.doi.org/10.1007/s00227-012-1895-8

Guerra-García J.M., García-Gómez J.C. 2001. The spatial distribution of Caprellidea (Crustacea: Amphipoda): a stress bioindicator in Ceuta (North Africa, Gibraltar area). PSZN Mar. Ecol 22: $357-367$. http://dx.doi.org/10.1046/j.1439-0485.2001.01757.x

Guerra-García J.M. García-Gómez J.C. 2004. Crustacean assemblages and sediment pollution in an exceptional case study: a harbour with two opposing entrances. Crustaceana 77(3): 353-370. http://dx.doi.org/10.1163/1568540041181538

Guerra-García J.M., Cabezas P., Baeza-Rojano E., et al. 2009. Is the north side of the Strait of Gibraltar more diverse than the south side? A case study using the intertidal peracarids (Crustacea: Malacostraca) associated to the seaweed Corallina elongata. J. Mar. Biol. Assoc. UK. 89(2): 387-397. http://dx.doi.org/10.1017/S0025315409002938

Guerra-García J.M., Navarro-Barranco C., Corzo J., et al. 2012. An illustrated key to the soft-bottom caprellids (Crustacea: Amphipoda) of the Iberian Peninsula and remarks to their ecological distribution along the Andalusian coast. Helgol. Mar. Res. 67(2): 321-336 http://dx.doi.org/10.1007/s10152-012-0324-1

Guitián F., Carballas T. 1976. Técnicas de análisis de suelos, 2nd ed. Pico Sacro, Santiago de Compostela, 276 pp.

Harmelin J.G. 1997. Diversity of bryozoans in a Mediterranean sublittoral cave with bathyal-like conditions; role of dispersal processes and local factors. Mar. Ecol. Prog. Ser. 153: 139-152. http://dx.doi.org/10.3354/meps153139

Horton T. 2008. Amphipoda from marine caves of Hong Kong Island. J. Nat. Hist. 42(9-12): 825-854 http://dx.doi.org/10.1080/00222930701860124

Long E.R., Field L.J., MacDonald D.D. 1998. Predicting toxicity in marine sediments with numerical sediment quality guidelines. Environ. Toxicol. Chem. 17: 714-727. http://dx.doi.org/10.1002/etc.5620170428

Lourido A., Moreira J., Troncoso J.S. 2008. Assemblages of peracarid crustaceans in subtidal sediments from the Ría de Aldán (Galicia, NW Spain). Helgol. Mar. Res. 62: 289-301. http://dx.doi.org/10.1007/s10152-008-0116-9

Manconi R., Serusi A., Pisera A. 2006. A new Mediterranean 'lithistid' sponge, Aciculites mediterranea sp. nov. (Porifera, Demospongiae) from a dark marine cave in Sardinia. J. Mar. Biol. Assoc. UK. 86: 691-698. http://dx.doi.org/10.1017/S0025315406013580

Manconi R, Ledda F.D, Serusi A, et al. 2009. Sponges of marine caves: Notes on the status of the Mediterranean palaeoendemic Petrobiona massiliana (Porifera: Calcarea: Lithonida) with new records from Sardinia. Ital. J. Zool. 76(3): 306-315. http://dx.doi.org/10.1080/11250000802629471

McCune B., Mefford M.J. 1997. PC-ORD. Multivariate scaling. Sage Publications, Beverly Hills, California, 60pp.

Moreira J., Gestoso L., Troncoso J.S. 2008. Diversity and temporal variation of peracarid fauna (Crustacea: Peracarida) in the sallow subtidal of a sandy beach: Playa América (Galicia, NW Spain). Mar. Ecol. 29 (1): 12-18 http://dx.doi.org/10.1111/j.1439-0485.2007.00195.x

Morrisey D.J., Howitt L., Underwood A.J., et al. 1992. Spatial variation in soft sediments benthos. Mar. Ecol. Prog. Ser. 81: 197-204.

http://dx.doi.org/10.3354/meps081197
Navarro-Barranco C., Guerra-García J.M., Sánchez-Tocino L., et al. 2012. Soft-bottom crustacean assemblages in Mediterranean marine caves: the cave of Cerro Gordo (Granada, Spain) as case study. Helgol. Mar. Res. 66(4): 567-576. http://dx.doi.org/10.1007/s10152-012-0292-5

Navarro-Barranco C., Guerra-García J.M., Sánchez-Tocino L., et al. 2013. Soft bottom diversity patterns in marine caves; Lessons from crustacean community. J. Exp. Mar. Biol. Ecol. 446: $22-28$.

http://dx.doi.org/10.1016/j.jembe.2013.04.009

Norén K., Lindegarth M. 2005. Spatial, temporal and interactive variability of infauna in Swedish coastal sediments. J. Exp. Mar. Biol. Ecol. 317: 53-68. http://dx.doi.org/10.1016/j.jembe.2004.11.014

Parravicini V., Guidetti P., Morri C., et al. 2010. Consequences of sea water temperature anomalies on a Mediterranean submarine cave ecosystem. Est. Coast. Shelf Sci. 86: 276-282. http://dx.doi.org/10.1016/j.ecss.2009.11.004

Pearson T.H., Rosenberg R. 1978. Macrobenthic succession in relation to organic enrichment and pollution of the marine environment. Oceanogr. Mar. Biol. 16: 229-311.

Pinedo S., Jordana E. 2007. Spain (Catalonia and Balearic Islands). In: Carletti A., Heiskanen A.S. (eds), Water Framework Directive Intercalibration Technical Report Part 3: Coastal and Transitional waters. JRC Scientific and Technical Reports, JRC and IES, pp. 62-70

Pinedo S., Jordana E., Salas F., et al. 2012. Testing MEDOCC and BOPA indices in shallow softbottom communities in the Spanish Mediterranean coastal waters. Ecol. Indic. 19: 98-105. http://dx.doi.org/10.1016/j.ecolind.2011.07.024

Rodriguez J., Molina F., Rodriguez M. 2003. Paraje Natural de los Acantilados de Maro-Cerro Gordo: nueva ZEPIM. Medio Ambiente 43: 16-19.

Riedl R. 1966. Biologie der Meereshöhlen. Verlag Paul Parey, Hamburg and Berlin, 702 pp.

Ruffo S. 1982-1998. The Amphipoda of the Mediterranean: Parts 1-4. Mém. Inst. Océanogr. Monaco 13: 1-959.

Scipione M.B., Taramelli E., Fresi E., et al. 1981. Distribuzione delle biocenosi bentoniche lungo un gradiente di luce in una grotta marina superficiale: Anfipodi. Memorie di Biologia Marina e di Oceanografia. 11(1): 1-16.

Shannon C.E., Weaver N. 1963. The Mathematical Theory of Communication. University of Illinois Press, Urbana, $111 \mathrm{pp}$.

Simboura N., Zenetos A. 2002. Benthic indicators to use in ecological quality classification of Mediterranean soft bottom marine ecosystems, including a new biotic index. Med. Mar. Sci. 3(2): 77-111.

Snelgrove P.V.R. 1998. The biodiversity of macrofaunal organisms in marine sediments. Biodivers. Conserv. 7: 1123-1132. http://dx.doi.org/10.1023/A:1008867313340

Underwood A.J. 1997. Experiments in ecology: their logical design and interpretation using analysis of variance. Cambridge University Press, Cambridge, 504 pp.

Underwood A.J., Chapman M.G., Richards S.A. 2002. GMAV-5 for Windows. An Analysis of Variance Programme. University of Sydney, Australia.

Vacelet J., Boury-Esnault N., Harmelin J.G. 1994. Hexactinellid cave, a unique deep-sea habitat in the scuba zone. Deep-Sea Res. 41 (7): 965-973. http.//dx doi.org/10.1016/0967-0637(94)90013-2

Zabala M., Riera T., Gili J.M., et al. 1989. Water flow, trophic depletion, and benthic macrofauna impoverishment in a submarine cave from the western Mediterranean. Mar. Ecol. 10: 271-287. http://dx.doi.org/10.1111/j.1439-0485.1989.tb00478.x 